\begin{tabular}{c} 
JURNAI, R IS'TI \\
IAll $\begin{array}{c}\text { (Rekayasa Sistem dan Teknologi Informasi) } \\
\text { Vol.4No.6(2020)1117-1123 }\end{array}$ \\
\hline
\end{tabular}

\title{
Sistem Pengecekan Toko Online Asli atau Dropship pada Shopee Menggunakan Algoritma Breadth First Search
}

\author{
Nurdin ${ }^{1}$, Muhammad Hutomi $^{2}$, Mukti Qamal $^{3}$, Bustami $^{4}$ \\ 1,2,3,4 Program Studi Teknik Informatika, Fakultas Teknik Universitas Malikussaleh \\ ${ }^{1}$ nurdin@unimal.ac.id
}

\begin{abstract}
The number of online shops on shopee e-commerce web makes it difficult for consumers to check the authenticity of online shops. This system is a system to check the genuine online shop or fake online shop (dropship) on Shopee e-commerce quickly and automatically according to the product keywords desired by consumers. Data checking or tracing is done by applying Breadth First Search (BFS) algorithm and data retrieval using web scraping techniques on Shopee e-commerce web with the keyword "men's shirt" the number of searches as many as 200 online shops based on three parameters namely type of delivery, store rating, and response rate from online shops. The stages carried out in this research started from the process of forming queues, visitors or browsing nodes, checking online shops, and the last one displayed the results of testing and system implementation. The results of this study showed that Breadth First Search algorithm is a simple algorithm that can be used to browse and check online shops automatically with good performance.
\end{abstract}

Keywords: online shop, BFS, Web Scraping, E-Commerce, Shopee

\begin{abstract}
Abstrak
Banyaknya toko online pada web e-commerce Shopee membuat konsumen kesulitan dalam mengecek keaslian toko online. Sistem ini merupakan sistem untuk melakukan pengecekan toko online asli atau toko online palsu (dropship) pada e-commerce Shopee secara cepat dan otomatis sesuai dengan kata kunci produk yang diinginkan oleh konsumen. Pengecekan atau penelusuran data dilakukan dengan menerapkan algoritma Breadth First Search (BFS) dan pengambilan data menggunakan teknik web scraping pada web e-commerce Shopee dengan kata kunci "kemeja pria" jumlah pencarian sebanyak 200 toko online berdasarkan tiga parameter yaitu jenis pengiriman, rating toko, serta response rate dari toko online. Tahapan yang dilakukan pada penelitian ini dimulai dari proses pembentukan queue, pengunjungan atau penjelajahan node, pengecekan toko online, dan yang terakhir menampilkan hasil pengujian serta implementasi sistem. Hasil penelitian ini menunjukan bahwa algoritma Breadth First Search merupakan algoritma sederhana yang mampu digunakan untuk melakukan penjelajahan sekaligus pengecekan toko online secara otomatis dengan performasi yang baik.
\end{abstract}

Kata kunci: Toko online, BFS, Web Scraping, E-Commerce, Shopee

\section{Pendahuluan}

digunakan untuk aktivitas e-commerce yaitu world wide Indonesia merupakan negara dengan tingkat pertumbuhan e-commerce tercepat di dunia. Pesatnya Shopee merupakan salah satu marketplace yang ada di pertumbuhan e-commerce Indonesia dikarenakan Indonesia. Shopee menyediakan berbagai macam jumlah pengguna internet di Indonesia melebihi dari 100 fasilitas serta beragam kategori barang yang menarik juta pengguna. Berdasarkan statistik, rata-rata pengguna untuk dibeli [3]. Dengan adanya Shopee mempermudah internet di Indonesia membelanjakan uangnya di situs konsumen atau pedagang melakukan transaksi jual beli perbelanjaan online mencapai Rp 3.190.000,- per orang produk secara online. Banyaknya toko online yang [1]. E-Commerce merupakan suatu proses jual beli menjual barang ataupun produk di situs Shopee produk secara elektronik oleh konsumen dan dari membuat konsumen kesulitan dalam menentukan toko perusahaan ke perusahaan dengan menggunakan online yang terbaik, membingungkan konsumen dalam komputer sebagai perantara transaksi bisnis. Media yang mencari harga terbaik, serta toko online dengan

Diterima Redaksi : 29-09-2020 | Selesai Revisi : 05-12-2020 | Diterbitkan Online : 20-12-2020 
pelayanan pengiriman terbaik. Selain itu, konsumen juga online Detik.com, dan Kompas.com untuk mengambil kesulitan untuk menentukan toko online asli atau data link url dari masing-masing media online. dropship sebelum melakukan pembelian pada produk Sedangkan penelitian penulis mengenai e-commerce yang diinginkan. Toko online asli adalah toko online Shopee untuk melakukan pengecekan toko online asli yang menjual sebagian besar barang/produknya secara atau dropship berdasarkan produk pencarian. Hanya saja langsung, memiliki gudang penyimpanan, dan memiliki terdapat persamaan dalam teknik pengambilan datanya. stok produk/barang yang siap dijual dan dikirim ke konsumen. Sedangkan toko online dropship adalah toko online yang tidak memiliki gudang penyimpanan dan tidak memiliki stok barang/produk yang siap untuk dikirim langsung ke konsumennya. Toko online dropship bukan berarti toko online yang berjualan produk/barang untuk menipu konsumennya, tetapi toko online yang menjual produk/barang dengan cara mengambil gambar produk orang lain untuk dipromosikan di tokonya [4].

Teknik Breadth First Search dapat digunakan dalam pencarian record dengan menelusuri URL utama hingga ke bagian terdalam link pada halaman artikel yang dilakukan pada media online, dari hasil penelitian menunjukan detik.com merupakan media online yang lebih banyak menghasilkan data yang relevan [8]. Breadth First Search juga lebih unggul daripada Depth First Search dalam mengumpulkan penjelajahan topik popular baik di tingkat global (seluruh Web) dan ditingkat nasional (domain.nl): Google Trends, Ada beberapa penelitian sebelumnya yang berhubungan WikiStats, dan Kueri dikumpulkan dari pengguna arsip dengan topik penelitian yang penulis lakukan, seperti surat kabar bersejarah Belanda [9]. Breadth First Search penelitian yang dilakukan oleh Sun dengan judul On memiliki efisiensi yang baik untuk sisi penjelajahan link Multi-Thread Crawler Optimization for Scalable Text URL [10]. Perbandingan antara DFS, BFS, BEFS dalam Searching dengan hasil penelitiannya membandingkan mencari geotagged image, dimana didapat algoritma antara algoritma BFS dan DFS, dimana didapatkan BFS dan DFS memiliki efisien waktu yang lebih baik bahwa algoritma BFS memiliki keunggulan dalam dari BEFS. Namun algoritma BEFS lebih baik dalam efisiensi waktu, sederhana, dan fleksibel dalam pendeteksian geotagged image yaitu sebesar $2 \%$ (201 pengunjungan halaman pada web Wikipedia. dari 9832 gambar), BFS sebesar $1.3 \%$ (52 dari 3898 Penjelajahan situs Wikipedia dengan BFS selama gambar), dan DFS 0.4\% (13 dari 3576 gambar) [11]. 273.05155 detik, sedangkan DFS 1000, 29163 detik [5]. Perbedaan dengan penelitian penulis ini yaitu proses pengunjungan web e-commerce Shopee dalam pengambilan data dengan menggunakan algoritma BFS dan untuk mengetahui status toko online yang dikunjungi asli atau dropship berdasarkan pada keyword pencarian yang pengguna masukkan ke dalam sistem pencarian.

Web Scraping adalah proses pengambilan sebuah dokumen semi-terstruktur dari internet, umumnya berupa halaman-halaman web dalam bahasa markup seperti HTML atau XHTML, dan menganalisis dokumen tersebut untuk diambil data. Web scraping sering dikenal sebagai screen scraping. Web Scraping tidak dapat dimasukkan dalam bidang data mining karena data mining menyiratkan upaya untuk memahami Penelitian Yadav dengan judul Design of a Novel pola semantik atau tren dari sejumlah besar data yang Interface for a Web Crawler [6]. Hasil yang didapat dari telah diperoleh [12]. Aplikasi web scraping (juga disebut penelitiannya yaitu membuktikan bahwasannya intelligent, automated, or autonomous agents) hanya algoritma BFS adalah algoritma yang sederhana yang fokus pada cara memperoleh data melalui pengambilan dapat digunakan untuk tujuan crawling halaman web dan ekstraksi data dengan ukuran data yang bervariasi http://www.cdlu.edu.in yang dibangun dengan ASP.Net [13]. Teknik Web Scraping juga dapat digunakan dalam dan bahasa VB. Tugas web crawler adalah menavigasi pengumpulan data promo pada situs e-commerce dalam web dan ekstrak halaman baru untuk penyimpanan di memberikan informasi promo yang sesuai [14] dan database [6]. Sedangkan penelitian penulis ini meneliti Penerapan text mining untuk melakukan clustering data mengenai e-commerce Shopee untuk mengambil data yang diterapkan pada tweet shopee [15].

halaman dengan bahasa pemrograman PHP dan Java Script.

Beberapa penelitian sebelumnya yang sudah penulis lakukan tentang sistem pengecekan/pendeteksian, antara Penelitian lainya yang berhubungan dengan penelitian lain sistem pendeteksian dengan metode Weight Tree ini, yaitu penelitian yang dilakukan oleh Pardede dengan yang diterapkan pada dokumen plagiarisme [16], dan judul Perbandingan Metode Breadth First Search dan sistem pendeteksian untuk mengukur kemiripan judul Backlink pada Web Crawler [7]. Hasil yang didapat dari dari skripsi mahasiswa dengan algoritma winnowing penelitiannya yaitu dengan perbandingan dalam [17].

pengambilan URL terbanyak pada Detik.com dan Kompas.com. BFS lebih unggul dari metode Backlink dalam web crawling, dengan jumlah URL mencapai $25,7 \%$ (Detik.com) dan 28,94\% (Kompas.com), Perbedaannya Penelitian yang dilakukan Jasman Pardede, dkk merupakan penelitian terhadap media

Adapun yang menjadi permasalahan dalam penelitian ini, karena setiap tahunnya jumlah toko online yang menjual barang/ produknya di Shopee terus bertambah. Banyaknya toko online yang terdapat dalam marketplace Shopee akan menyulitkan komsumen 
dalam menentukan apakah toko online yang menjual First Search sebagai berikut. Penerapan algoritma barang yang diinginkan konsumen tersebut apakah toko Breadth First Search dapat dilihat pada Gambar 1 online yang terbaik dari beberapa aspek seperti memiliki berikut.

stok di gudangnya atau tidak, memiliki harga penjualan terbaik atau tidak, serta memiliki pelayanan pengiriman yang terbaik atau tidak. Dengan mengecek keaslian toko online, memungkinakn barang yang diinginkan konsumen dapat dikirimkan dihari yang sama, karena terdapat proses pengiriman sameday service dan instant. Selain itu juga akan memberikan harga yang wajar kepada konsumen, karena tidak melakukan margin up yang berlebih. Maka dibutuhkan sebuah sistem yang mampu melakukan proses pengecekan toko online secara otomatis dan cepat, memudahkan konsumen dalam pengecekan toko online asli secara efisien sebelum melakukan transaksi, selain itu dapat memberikan rekomendasi pemilihan toko online asli kepada konsumen untuk mendapatkan toko online yang memiliki pelayanan, jenis pengiriman, serta rating toko yang terbaik.

Penelitian ini bertujuan untuk mempermudah konsumen dalam memilih toko online asli sebelum membeli produk Pada gambar 1 di atas, yang menjadi node level 0 yaitu dari toko online yang ada di Shopee secara efektif dan keyword pencarian toko berdasarkan pencarian produk, efisien. Mempermudah konsumen dalam melakukan dimana setiap keyword pencarian memiliki produk yang pengecekan keaslian toko online asli pada e-commerce akan diambil shopid sebagai node level 1 dan itemid Shopee secara cepat dan otomatis sesuai dengan kata sebagai node level 2 dari skema BFS pada penelitian ini. kunci produk yang konsumen inginkan. Membantu konsumen dalam proses penelusuran toko online asli yang menjual produk yang diinginkan oleh konsumen secara otomatis. Memberikan rekomendasi toko online terbaik kepada konsumen sebelum melakukan proses pembelian produk. Selain itu dapat mengetahui bagaimana performansi algoritma Breadth First Search dalam penelusuran toko online.

\section{Metode Penelitian}

\subsection{Jenis dan sumber data}

Jenis data primer yang digunakan dalam penelitian ini adalah data informasi toko online yang ada pada situs Shopee (marketplace Shopee), dengan kata kunci "Kemeja Pria", proses pengambilan data dilakukan secara realtime. Data-data yang diambil adalah link keseluruhan toko online yang tertera berdasarkan keyword yang dimasukkan kemudian diambil informasi toko online seperti jumlah produk terjual, penilaian produk, jumlah produk terjual secara keseluruhan, penilaian produk secara keseluruhan, lama waktu bergabung, persentase chat dibalas, waktu chat dibalas, penilaian toko.

\subsection{Algoritma Breadth First Search}

Dalam penelitian ini algoritma yang digunakan yaitu algoritma Breadth First Search, yang digunakan sebagai proses pencarian sekalian pengunjungan link toko online berdasarkan keyword yang dimasukkan, kemudian diambil data berupa shopid dan itemid yang digunakan sebagai node. Adapun penerapan algoritma Breadth

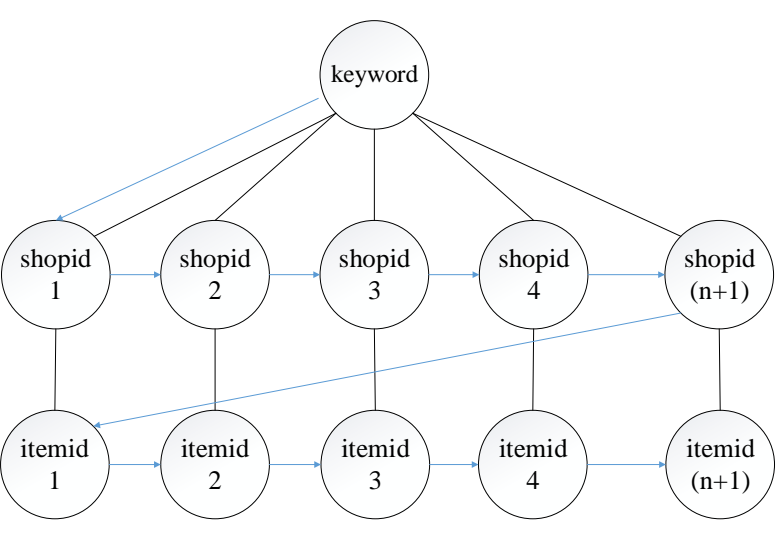

Gambar 1. Algoritma Breadth First Search

BFS: :keyword, shopid 1, shopid 2, shopid 3, shopid $4, \ldots$. shopid $(n+1)$, itemid 1 , itemid 2 , itemid 3 , itemid $4, \ldots$. , itemid $(\mathrm{n}+1)$.

\subsection{Skema Sistem}

Berikut skema sistem pengecekan toko online asli atau dropship pada e-commerce shopee. Skema sistem pada penelitian ini dapat dilihat pada Gambar 2.

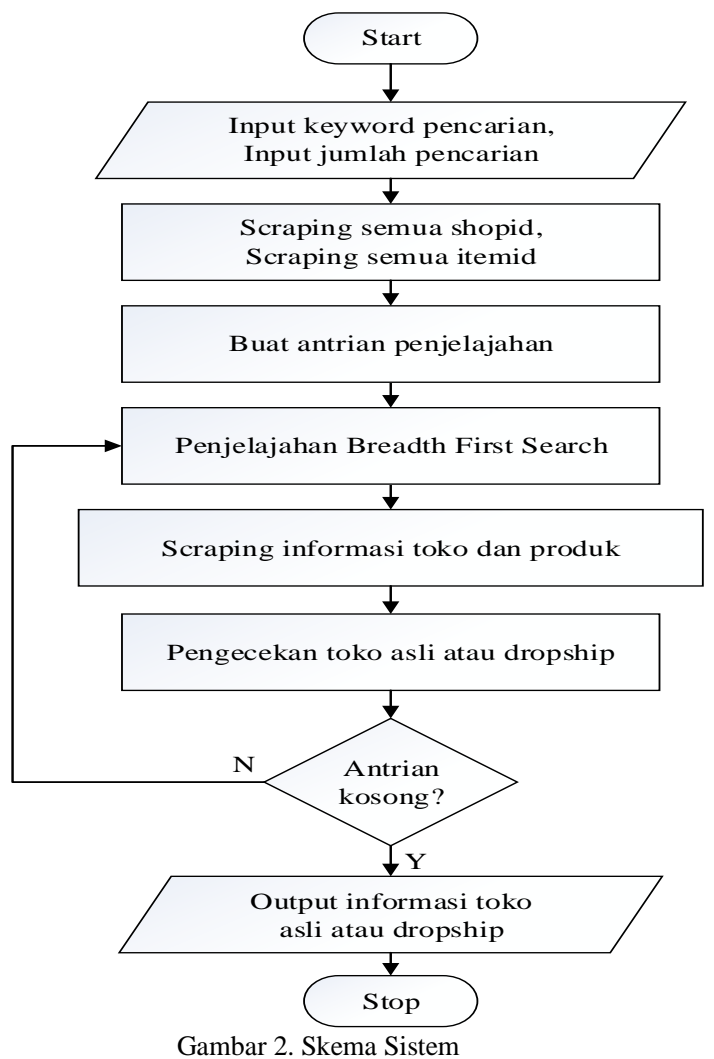

Jurnal RESTI (Rekayasa Sistem dan Teknologi Informasi) Vol . 4 No. 6 (2020) 1117 - 1123 
Skema sistem diatas adalah skema yang dari pohon pembentukan queue akan menampung node menggambarkan mengenai proses perancangan itemid yang digunakan sebagai node untuk keseluruhan sistem sebagai berikut: pengunjungan produk dari toko online yang dibentuk

a. Start: merupakan proses inisialisasi awal memulai aplikasi.

b. Input keyword pencarian, input jumlah pencarian: merupakan proses memasukkan keyword (kata kunci) pencarian, serta jumlah pencarian yang akan dilakukan.

antriannya. Pada penelitian ini penulis melakukan pengecekan terhadap 200 toko online. Berikut data antrian yang berhasil dibangun diperlihatkan pada Tabel 1.

Scraping semua shopid, scraping semua itemid: merupakan proses untuk mengambil seluruh shopid dan itemid hasil dari pencarian berdasarkan keyword.

d. Buat antrian penjelajahan: proses untuk membuat antrian penjelajahan untuk penerapaan algoritma Breadth First Search.

e. Penjelajahan Breadth First Search: merupakan proses penjelajahan shopid dan itemid dari antrian dengan algoritma Breadth First Search.

f. Scraping informasi toko dan produk: merupakan proses untuk mengambil informasi toko dan produk berdasarkan keyword pencarian.

g. Pengecekan toko asli atau dropship: merupakan proses untuk pengecekan apakah toko online asli atau dropship dengan kriteria yang sudah ditentukan.

h. Antrian kosong?: merupakan proses untuk mengecek apakah antrian penjelajahan masih ada atau tidak. Jika masih ada, maka akan dilakukan penjelajahan Breadth First Search kembali. Jika tidak ada, maka ke proses selanjutnya.

i. Output informasi toko asli atau dropship: adalah proses untuk menampilkan apakah toko online asli atau dropship.

j. Stop: merupakan proses perhentian dari aplikasi.

\section{Hasil dan Pembahasan}

Penerapan algoritma Breadth First Search pada penelitian ini menjelaskan implementasi dan melakukan pengujian algoritma BFS terhadap penjelajahan link sekaligus pengambilan data serta menjelaskan hasil dari pengujian algoritma Breadth First Search pada sistem pengecekan toko online asli atau dropship pada web ecommerce shopee.

\subsection{Pembentukan Queue}

Pada tahap ini merupakan pembentukan queue (antrian) untuk pengunjungan node menggunakan algoritma Breadth First Search. Adapun pada tahap ini sistem yang dibangun akan membangun antrian secara otomatis berdasarkan pada keyword pencarian yang pengguna masukkan. Keyword pencarian akan menjadi source node/root node. Setiap node akan menyimpan satu kode yang bersifat unik dan akan digunakan untuk pengunjungan link nantinya. Pada layer pertama dari pembentukan pohon queue akan digunakan untuk menampung node shopid yang bersifat unik untuk pengunjungan dari toko online, serta pada layer kedua

Tabel 1. Pembentukan Queue

\begin{tabular}{rlll}
\hline \multicolumn{1}{c}{ No } & Layer & \multicolumn{1}{c}{ Data } & \multicolumn{1}{c}{ Keterangan } \\
\hline 1 & 0 & Kemeja Pria & Root Node \\
2 & 1 & 43407166 & Node ke 1 (shop id 1) \\
3 & 1 & 10683489 & Node ke 2 (shop id 2) \\
5 & 1 & 9539215 & Node ke 3 (shop id 3) \\
6 & 1 & 63993172 & Node ke 4 (shop id 4) \\
7 & 1 & 60458803 & Node ke 5 (shop id 5) \\
$\ldots$. & $\ldots$. & $\ldots$ & Node ke 6 (shop id 6) \\
202 & 1 & 5912050 & Node ke 200 (shop id 200) \\
203 & 2 & 1032996706 & Node ke 201 (item id 1) \\
204 & 2 & 1036401498 & Node ke 202 (item id 2) \\
205 & 2 & 1085546030 & Node ke 203 (item id 3) \\
206 & 2 & 1143526796 & Node ke 204 (item id 4) \\
207 & 2 & 1160795332 & Node ke 205 (item id 5) \\
208 & 2 & 1162975002 & Node ke 206 (item id 6) \\
$\ldots$. & $\ldots$. & $\ldots$. & $\ldots .$. \\
401 & 2 & 862819086 & Node ke 400 (item id 200) \\
\hline
\end{tabular}

\subsection{Pengunjungan Node}

Setelah pembentukan queue selesai dilakukan, maka akan dilanjutkan dengan tahap pengunjungan quеие (antrian) yang telah dibentuk sebelumnya. Proses pengunjungan node sesuai dengan algoritma Breadth First Search yaitu dengan FIFO (First in First Out) dimana node yang pertama dimasukkan kedalam antrian maka dia akan dikeluarkan. Pada tahap ini, setiap node dalam antrian akan diknjungi satu per satu. Setelah dikunjungi akan dilakukan proses pengambilan data (scraping data) pada halaman tersebut. Adapun data yang diambil yaitu data toko seperti nama toko, jumlah produk, lokasi toko, rating toko, pemilik toko, rating baik, rating normal, rating buruk, following, follower, response rate, serta pengiriman. Dan data produk seperti nama produk, harga produk, produk terjual, status produk, rating produk, rating dengan foto, rating dengan teks, jumlah penilai (reviewer), bintang 1, bintang 2, bintang 3, bintang 4, bintang 5, serta link gambar produk. Namun yang menjadi fokus penulis yaitu pada beberapa atribut pada data toko seperti nama toko, lokasi toko, jenis pengiriman, rating toko, serta response rate. Data ini akan digunakan pada tahap pengecekan toko online nantinya. Adapun data toko online dapat dilihat pada Tabel 2.

Tabel 2. Data Toko

\begin{tabular}{lllll}
\hline No & $\begin{array}{c}\text { Nama } \\
\text { Toko }\end{array}$ & Pengiriman & Rating & Response \\
\hline
\end{tabular}




\begin{tabular}{|c|c|c|c|c|}
\hline 1 & $\mathrm{X} 1$ & $\begin{array}{l}\text { Reguler, Same Day, } \\
\text { Reguler (Cargo), } \\
\text { Instant }\end{array}$ & 4.8 & 94 \\
\hline 2 & $\mathrm{X} 2$ & $\begin{array}{c}\text { Reguler, Reguler } \\
\text { (Cargo) }\end{array}$ & 4.9 & 57 \\
\hline 3 & $\mathrm{X} 3$ & Reguler, Next Day & 4.9 & 92 \\
\hline 4 & $\mathrm{X} 4$ & Shopee Logistics & 4.2 & 76 \\
\hline 5 & $\mathrm{X} 5$ & Reguler, Next Day & 4.6 & 71 \\
\hline 6 & X6 & $\begin{array}{l}\text { Reguler, Reguler } \\
\text { (Cargo) }\end{array}$ & 4.8 & 97 \\
\hline 7 & $\mathrm{X} 7$ & $\begin{array}{c}\text { Reguler, Same Day, } \\
\text { Reguler (Cargo), } \\
\text { Instant }\end{array}$ & 4.7 & 99 \\
\hline 8 & $\mathrm{X} 8$ & $\begin{array}{l}\text { Reguler, Reguler } \\
\text { (Cargo), Next Day }\end{array}$ & 4.8 & 96 \\
\hline 9 & X9 & $\begin{array}{l}\text { Reguler, Reguler } \\
\text { (Cargo) }\end{array}$ & 4.5 & 94 \\
\hline 10 & $\mathrm{X} 10$ & $\begin{array}{l}\text { Reguler, Reguler } \\
\text { (Cargo) }\end{array}$ & 4.6 & 100 \\
\hline 11 & X11 & $\begin{array}{l}\text { Reguler, Same Day, } \\
\text { Reguler (Cargo), } \\
\text { Next Day }\end{array}$ & 4.4 & 96 \\
\hline 12 & $\mathrm{X} 12$ & $\begin{array}{l}\text { Reguler, Same Day, } \\
\text { Reguler (Cargo) }\end{array}$ & 4.7 & 82 \\
\hline 13 & X13 & $\begin{array}{l}\text { Reguler, Reguler } \\
\text { (Cargo) }\end{array}$ & 4.6 & 96 \\
\hline 19 & X19 & Reguler & 4.6 & 94 \\
\hline 20 & $\mathrm{X} 20$ & Reguler & 4.6 & 97 \\
\hline$\cdots$ & $\cdots$ & $\ldots$ & $\cdots$ & $\cdots$ \\
\hline 200 & X200 & Reguler & 4.7 & 98 \\
\hline
\end{tabular}

\subsection{Kriteria Pengecekan Toko Online}

Penentuan toko online dilakukan dengan berdasarkan data yang didapat dalam proses pencarian atau pengunjungan node. Kriteria pengecekan toko online asli atau dropship didasarkan pada beberapa kriteria pada toko online, seperti yang terlihat pada Tabel 3.

Tabel 3. Kriteria Pengcekan Toko Online

\begin{tabular}{lll}
\hline \multirow{2}{*}{ Parameter } & \multicolumn{2}{c}{ Toko Online } \\
\cline { 2 - 3 } Pengiriman & \multicolumn{1}{c}{ Asli } & \multicolumn{1}{c}{ Dropship } \\
& $\begin{array}{l}\text { Terdapat } \\
\text { pengiriman }\end{array}$ & $\begin{array}{l}\text { Hanya terdapat } \\
\text { pengiriman Shope }\end{array}$ \\
& Service, Snstant & Logistics \\
Rating Toko & $\geq 4$ & $<4$ \\
Response Rate & $\geq 90 \%$ & $<90 \%$ \\
\hline
\end{tabular}

Alasan dalam penentuan kriteria pengecekan toko online:

1. Pengiriman (Reguler, Same Day Service atau Instant) sebagai parameter toko online asli dikarenakan dengan adanya pengiriman regular maka toko online tersebut memungkinkan memiliki toko online fisik, serta Same Day dan Instant merupakan jenis pengiriman yang melayani pengiriman dihari yang sama dengan pesanan konsumen. Hasil penelaahan penulis jika toko online memiliki jenis pengiriman ini maka toko tersebut dapat dikategorikan memiliki stok produk di gudangnya sehingga dapat mengirimkan barang dihari yang sama.

2. Pengiriman (Shopee Logistics) sebagai parameter toko online dropship dikarenakan pengiriman Shopee Logistics merupakan jenis pengiriman dari luar negeri. Hasil penelaahan penulis jika toko online memiliki jenis pengiriman ini maka toko online tersebut dapat dikategorikan menjualkan barang/produk orang lain dengan cara mengambil gambar dan mempromosikan di toko onlinenya.

3. Rating toko $(\geq 4)$ sebagai parameter toko online asli dikarenakan rating dengan nilai $\geq 4$ merupkan angka minimal sebuah toko online yang dapat dipercaya, karena telah berhasil menjual dan transaksi berhasil diatas $80 \%$.

4. Rating toko $(<4)$ sebagai parameter toko online dropship dikarenakan total transaksi berhasil dari toko online tersebut di bawah $80 \%$.

5. Response rate ( $\geq 90 \%)$ sebagai parameter toko online asli dikarenakan toko online ini memiliki response terhadap konsumen sangat baik, waktu pengiriman barang yang tepat waktu, serta cepat dalam menanggapi tanggapan dari konsumennya.

6. Response rate $(<90 \%)$ sebagai parameter toko online dropship dikarenakan toko online ini memiliki response terhadap konsumen kurang tanggap, waktu pengiriman barang yang terkadang tidak tepat waktu, serta sedikit agak lama dalam menanggapi tanggapan dari konsumennya.

\subsection{Hasil Pengujian}

Setelah dilakukan pengujian data toko berdasarkan kriteria penentuan pengecekan toko online yang telah disebutkan di atas, maka didapat status toko online. Adapun data status toko online ditampilkan pada Tabel 4.

Tabel 4. Data Status Toko Online

\begin{tabular}{lllll}
\hline \multirow{2}{*}{ No } & \multirow{2}{*}{ Toko } & \multicolumn{3}{c}{ Status Toko Online Berdasarkan } \\
\cline { 3 - 5 } & & Pengiriman & Rating Toko & Response Rate \\
\hline 1 & X1 & Asli & Asli & Asli \\
2 & X2 & Asli & Asli & Dropship \\
3 & X3 & Asli & Asli & Asli \\
4 & X4 & Dropship & Asli & Dropship \\
5 & X5 & Asli & Asli & Dropship \\
6 & X6 & Asli & Asli & Dropship \\
7 & X7 & Asli & Asli & Asli \\
8 & X8 & Asli & Asli & Asli \\
9 & X9 & Asli & Asli & Asli \\
10 & X10 & Asli & Asli & Asli \\
11 & X11 & Asli & Asli & Asli \\
12 & X12 & Asli & Asli & Asli \\
13 & X13 & Asli & Asli & Dropship \\
14 & X14 & Asli & Asli & Asli \\
15 & X15 & Asli & Asli & Asli \\
16 & X16 & Asli & Asli & Dropship \\
17 & X17 & Asli & Asli & Asli \\
18 & X18 & Asli & Asli & Dropship \\
19 & X19 & Asli & Asli & Dropship \\
20 & X20 & Asli & Asli & Asli \\
& & & &
\end{tabular}




\begin{tabular}{lllll}
\hline$\ldots$. & $\ldots$ & $\ldots$ & $\ldots$ & $\ldots$ \\
200 & X200 & Asli & Asli & Asli \\
\hline
\end{tabular}

Dari data pengujian di atas, penulis mendapatkan data bahwasannya aplikasi dapat melakukan pengecekan toko online dengan baik, dari keyword "Kemeja Pria" dengan banyak pencarian 200 data toko online yang berbeda. Waktu yang diperlukan sistem untuk melakukan pengunjungan setiap node, dari node pertama hingga node 400 dengan menerapkan algoritma Breadth First Search dibutuhkan waktu sekitar 219.485 sekon. Dengan jumlah pengecekan berdasarkan pengiriman didapat 196 toko online asli dan 4 dropship, berdasarkan rating toko didapat 198 toko online asli dan 2 dropship, serta berdasarkan response rate didapat 129 toko online asli dan 71 dropship.

\subsection{Pengujian Performasi BFS}

Berdasarkan observasi algoritma Breadth First Search memiliki performasi yang cukup baik dalam pencarian data yang relevan seperti yang terlihat pada Tabel 5 .

Tabel 5. Performasi Algoritma BFS

\begin{tabular}{ccc}
\hline Algoritma & Pencarian & Halaman Relevan \\
\hline$B F S$ & 200 & 147 \\
\hline
\end{tabular}

\subsection{Implementasi Sistem}

Implementasi sistem pada tahap ini melanjutkan kontruksi aplikasi dari metode prototype yaitu implementasi dari perancangan sistem yang telah didefinisikan sebelumnya. Tampilan program akan digunakan pengguna untuk berinteaksi dengan perangkat lunak yang dibangun. Implementasi sistem digunakan sebagai tolak ukur pengujian dari hasil program yang sudah dibuat untuk pembangunan sistem.

\section{a. Halaman Hasil Pencarian}

Halaman ini merupakan halaman hasil pencarian toko online berdasarkan keyword dan jumlah pencarian yang dimasukkan oleh pengguna sebagai berikut. Halaman hasil pencarian dapat dilihat pada gambar 4.

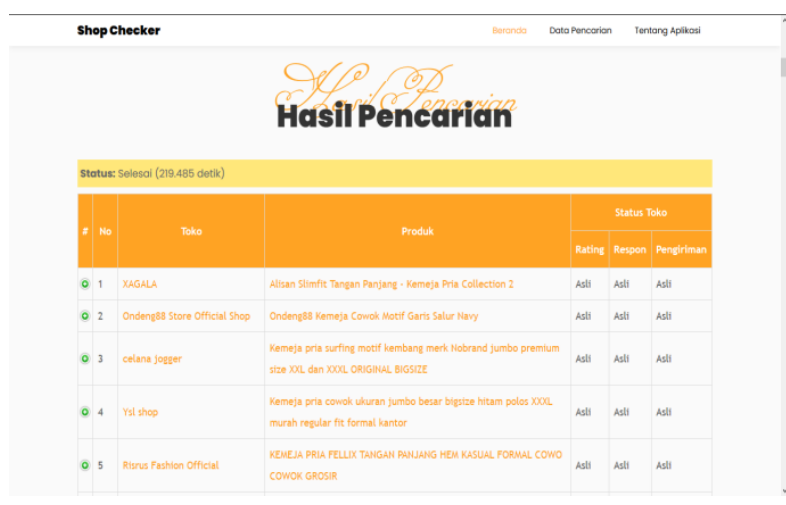

Gambar 4. Halaman Hasil Pencarian

b. Halaman Detil Hasil Pencarian
Halaman ini merupakan halaman untuk menampilkan hasil pencarian toko online berdasarkan keyword yang dimasukkan. Di halaman ini terdapat tabel yang menampilkan nama produk, nama toko, serta status toko. Disamping itu, apabila tombol plus (+) ditekan, maka akan menampilkan detail pencarian dapat dilihat pada gambar dibawah ini. Halaman detil hasil pencarian dapat dilihat pada Gambar 5.

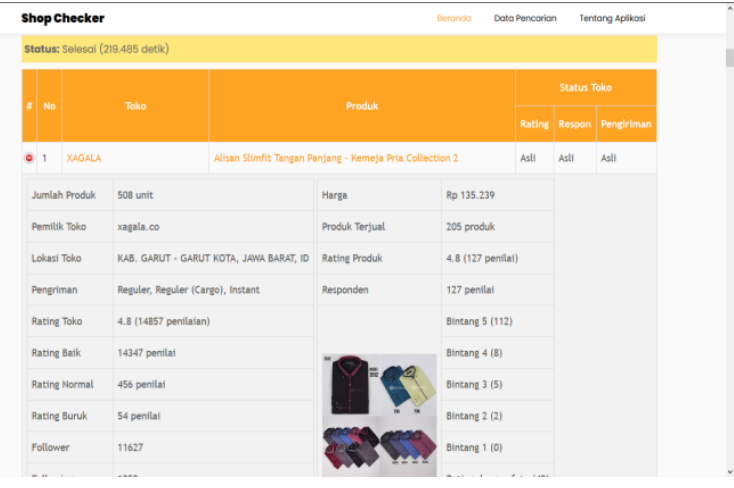

Gambar 5. Halaman Detil Hasil Pencarian

\section{c. Halaman Data Pencarian Pencarian}

Halaman ini merupakan halaman yang menampilkan hasil pencarian toko online dan produk yang telah dilakukan sebelumnya, seluruh data pencarian seperti yang ditampilkan pada Gambar 6.

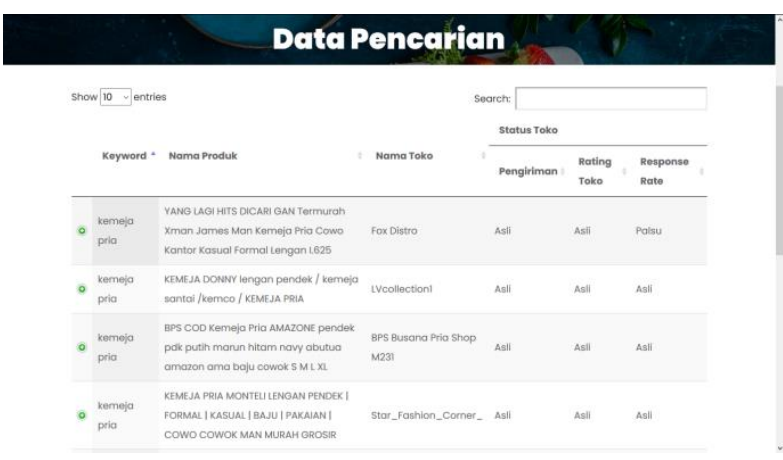

Gambar 6. Halaman Data Pencarian

\section{d. Halaman Data Toko}

Halaman ini berguna untuk menampilkan keseluruhan data pencarian toko online yang telah dilakukan oleh pengguna sebelumnya, serta akan menampilkan detail dari toko online yang ingin dilihat informasi detailnya. Halaman data toko dapat dilihat pada gambar 7. 


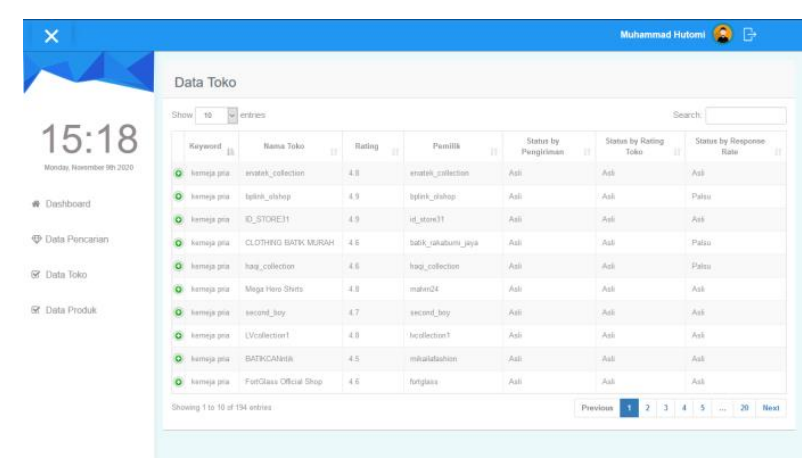

Gambar 7. Halaman Data Toko Online

\section{e. Halaman Data Produk}

Halaman ini berguna untuk menampilkan keseluruhan data pencarian produk yang telah dilakukan oleh [8] pengguna sebelumnya, serta akan menampilkan detail dari produk yang ingin dilihat informasi detailnya. Halaman data produk dapat dilihat pada Gambar 8.

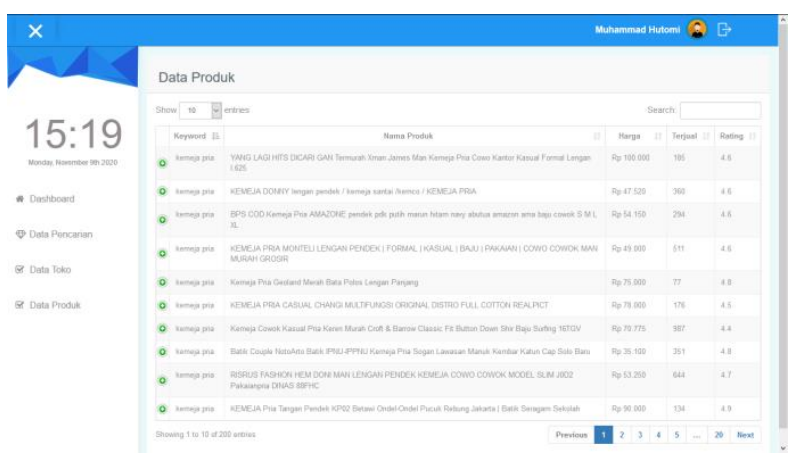

Gambar 8. Halaman Data Produk

\section{Kesimpulan}

Berdasarkan penelitian yang telah dilakukan, sistem pengecekan toko online yang dibangun dapat melakukan pengecekan toko online dengan baik, berdasarkan parameter pengiriman, rating toko, serta response rate. Hasil penelitian terhadap keyword "Kemeja Pria" dengan jumlah pencarian 200 toko online menghasilkan pengecekan toko online berdasarkan parameter pengiriman 196 toko online asli dan 4 dropship, berdasarkan rating toko didapat 198 toko online asli dan 2 dropship, serta berdasarkan response rate didapat 129 toko online asli dan 71 dropship. Hasil pengecekan toko online tidak serta-merta mengkategorikan suatu toko online tersebut asli atau dropship secara keseluruhan, akan tetapi dicek berdasarkan parameter, sehingga memungkinkan bisa dalam satu parameter dikatakan kategori toko online asli, dan pada salah satu parameter lainnya dikategorikan sebagai toko online dropship.

\section{Daftar Rujukan}

[1] "Indonesia Jadi Negara dengan Pertumbuhan E-Commerce Tercepat di Dunia | Databoks.” https://databoks.katadata.co.id/datapublish/2019/04/25/indones ia-jadi-negara-dengan-pertumbuhan-e-commerce-tercepat-didunia (accessed Dec. 03, 2020).

[2] S. M. Maulana, H. Susilo, and Riyadi, "Implementasi ECommerce Sebagai Media Penjualan Online (Studi Kasus Pada Toko Pastbrik Kota Malang)," J. Adm. Bisnis, 2015.

[3] "Apa itu Shopee? Keunggulan Apa Saja yang Dimiliki oleh Shopee?" https:/www.nesabamedia.com/apa-itu-shopee/ (accessed Dec. 03, 2020).

[4] "Cara Membedakan Online Shop Asli dan Palsu di Shopee BAJUYULI - Blog." https://blog.bajuyuli.com/2017/10/tokoonline-asli-palsu-shopee.html (accessed Dec. 03, 2020).

[5] G. Sun, H. Xiang, and S. Li, "On Multi-Thread Crawler Optimization for Scalable Text Searching," J. Big Data, vol. 1, no. 2, pp. 89-106, 2019, doi: 10.32604/jbd.2019.07235.

[6] M. Yadav, "D e s i g n o f a N ove l In t e r f a c e for a W e b C r a w 1 e r," Int. J. Electron. Eng., vol. 11, no. 1, pp. 952958, 2019.

[7] J. Pardede, A. N. Hermana, and G. Swarghani, "Perbandingan Metode Breadth First Search dan Backlink pada Web Crawler," MIND J., vol. 2, no. 2, pp. 61-69, 2018, doi: 10.26760/mindjournal.v2i2.61-69.

I. P. Sonya and Prihandoko, "Analisis Web Scraping untuk Data Bencana Alam dengan Menggunakan Teknik Breadth-First Search Terhadap 3 Media Online," J. Ilm. Inform. Komput. Univ. Gunadarma, vol. 21, no. 3, pp. 69-77, 2016.

[9] T. Samar, M. C. Traub, J. van Ossenbruggen, and A. P. de Vries, "Comparing topic coverage in breadth-first and depth-first crawls using anchor texts," Lect. Notes Comput. Sci. (including Subser. Lect. Notes Artif. Intell. Lect. Notes Bioinformatics), vol. 9819 LNCS, pp. 133-146, 2016, doi: 10.1007/978-3-31943997-6_11.

[10] A. M. Tanvir, Y. Kim, and M. Chung, "Design and Implementation of an Efficient Web Crawling Using Neural Network," 2020, doi: 10.1007/978-981-13-9341-9_20.

[11] N. Fazal, K. Q. Nguyen, and P. Fränti, "Efficiency of web crawling for geotagged image retrieval," Webology, vol. 16, no. 1, pp. 16-39, 2019, doi: 10.14704/web/v16i1/a177.

[12] A. Josi, L. A. Abdillah, and Suryayusra, "Penerapan teknik web scraping pada mesin pencari artikel ilmiah," 2014, [Online]. Available: http://arxiv.org/abs/1410.5777.

[13] R. C. Wijaya, J. Andjarwirawan, and H. N. Palit, "Aplikasi Pencarian Produk Jual Mobile Devices dari Berbagai Situs Ecommerce," J. Infra, 2016.

[14] F. R. Wibowo, D. S. Rusdianto, and A. Arwan, "Pengembangan Sistem Pengumpulan Promo E-Commerce Berbasis Website Dengan Menerapkan Teknik Web Scraping Dalam Proses Pengambilan Data Promo," J. Pengemb. Teknol. Inf. dan Ilmu Komput., vol. 3, no. 3, pp. 2887-2893, 2019.

[15] D. S. Indraloka and B. Santosa, "Penerapan Text Mining untuk Melakukan Clustering Data Tweet Shopee Indonesia," J. Sains dan Seni ITS, 2017, doi: 10.12962/j23373520.v6i2.24419.

[16] N. Nurdin, R. Rizal, and R. Rizwan, "Pendeteksian Dokumen Plagiarisme dengan Menggunakan Metode Weight Tree," Telematika, 2019, doi: 10.35671/telematika.v12i1.775.

[17] N. Nurdin and A. Munthoha, "SISTEM PENDETEKSIAN KEMIRIPAN JUDUL SKRIPSI MENGGUNAKAN ALGORITMA WINNOWING," InfoTekJar (Jurnal Nas. Inform. dan Teknol. Jaringan), 2017, doi: 10.30743/infotekjar.v2i1.165. 